\title{
Incontinentia Lactis: Physiology and Anatomy Conducive to Milk Leakage in Dairy Cows
}

\author{
M. Rovai, M. T. Kollmann, and R. M. Bruckmaier ${ }^{1}$ \\ Physiology Weihenstephan, Technical University Munich, Weihenstephaner Berg 3, D-85350 Freising, Germany
}

\begin{abstract}
Incontinentia lactis is a possible predisposing factor for an elevated level of intramammary infection. The goal of the present study was to investigate possible causes of incontinentia lactis in dairy cows. Two farms that differed in breed composition, but that had similar average milk yields were studied: herd A, $28 \mathrm{~kg} / \mathrm{d}, 31$ Red Holstein cows; and herd B, 26 kg/d, 16 Brown Swiss cows. Herd A was classified into 2 groups: incontinentia lactis (ILA group) and control, whereas herd B was exclusively a control herd. Milk samples that represented foremilk and the main milk fraction were collected during 4 milking sessions. In addition, milk leakage samples from the ILA group were collected at different time intervals from 0 to $5 \mathrm{~h}$ before milking. Measurements of the teat, milk flow, fractions of cisternal and alveolar milk, intramammary pressure, and blood oxytocin pattern also were obtained. The ILA cows did not have differences in fat content between milk leakage and cisternal milk fraction. Milk fat content, however, increased during milking in response to continuous milk ejection $(1.95,1.99$, and $4.61 \%$ for milk leakage, cisternal, and main milk samples, respectively). Teat canals were 9\% shorter in the ILA cows, which showed greater milk yield, peak, and average flow rates. Quarter cisternal milk yield of ILA cows tended to be greater $(0.50$ vs. 0.23 and $0.28 \mathrm{~kg}$ for ILA and controls from herds A and B, respectively), whereas percentages of cistern milk and alveolar milk did not differ from controls. The greater pressure in the ILA group, both before and after manual udder stimulation (ILA: 4.0 and $6.4 \mathrm{kPa}$; control: 2.0 and $5.0 \mathrm{kPa}$, respectively), could be an important cause for the leakage. Nevertheless, the increase in IMP that occurred after udder preparation affirms that milk ejection occurred in response to the tactile teat stimulation, but not before the onset of leakage. Blood oxytocin concentration in ILA cows was low until the start of udder preparation and increased in response to the milking stimulus (reaf-
\end{abstract}

Received April 17, 2006.

Accepted September 18, 2006.

${ }^{1}$ Corresponding author: rupert.bruckmaier@physio.unibe.ch firming the hypothesis that milk leakage occurred in the absence of milk ejection). In conclusion, milk losses by leakage are likely due to the large amount of cisternal milk, which creates pressure and causes leakage, in the absence of milk ejection.

Key words: incontinentia lactis, milk leakage, cattle

\section{INTRODUCTION}

Milk leakage, in the absence of active milking, is a potentially detrimental factor that many dairy producers observe daily. Involuntary release of milk from nonstimulated teats (incontinentia lactis) frequently occurs between milkings when cows are lying down or shortly before entering the milking parlor.

The condition of milk leakage may have an effect on dairy herd management because it has been shown to be associated with an increase in the incidence of clinical mastitis (Schukken et al., 1990; Waage et al., 1998; Barkema et al., 1999). In particular, milk leakage at a time when a lactating cow is recumbent in a stall predisposes her to Escherichia coli infection because the open teat canal may be exposed to fecal contaminants (Schukken et al., 1991).

Milk leakage has received little attention, and thus, its incidence in dairy herds is largely unreported. Schukken et al. (1993) found that approximately $30 \%$ of 68 Holstein-Friesian cows during the early dry-off period displayed milk leakage. Milk loss by incontinentia lactis is common among high-yielding cows (Schukken et al., 1990; Peeler et al., 2000). This association, however, was not confirmed in a recent study (Klaas et al., 2005) in which its occurrence was related with high peak flow rate, but not with high milk yield.

Anatomical characteristics such as teat canal length and teat length and width as well as functional traits (e.g., milk flow profiles and teat condition) of the teat are presumed to have considerable influence on milkability (Baxter et al., 1950; Weiss et al., 2004) and udder health (Grindal and Hillerton, 1991). Milkability is the adaptation and performance of dairy animals to the machine milking process, and is influenced by production level, udder morphology, milking fractions and kinetics, and milking time. The teat canal is the interface between the environment and the mammary cistern. It plays an 
important role as the primary defensive barrier against mastitis pathogens. In fact, any teat injury (e.g., teat canal protrusion) that greatly increases the degree of exposure of the mammary gland to pathogens may also predispose the udder to milk leakage, by negatively influencing hygiene and milking efficiency (Grindal and Hillerton, 1991).

Previous studies (Persson Waller et al., 2003; Klaas et al., 2005) reported occurrence of milk leakage at all stages of lactation and levels of production. No difference was detected among dairy breeds under different milking systems. These studies tried to identify possible predisposing factors for incontinentia lactis such as teat traits and milkability. Relevant physiological factors [e.g., hormones, milk fractioning, milk quality, intramammary pressure (IMP) and milk ejection], however, that might be associated with occurrence of milk leakage remain to be investigated.

The objective of the present study was to identify the physiological and anatomical factors that favor milk leakage. Relationship between the condition of milk leakage and the milk ejection reflex also was evaluated.

\section{MATERIALS AND METHODS}

\section{Animals, Feeding, and Milking}

The present study was conducted on 2 experimental farms of the Technical University Munich (Germany) using 47 dairy cows. The herds differed in breed composition, but had similar production levels. Herd A comprised Red Holstein cows (RH; $28 \mathrm{~kg} / \mathrm{d}$ ) in which 18 cows were assigned to an incontinentia lactis group (ILA) and 13 cows to a control group. Herd B comprised Brown Swiss cows (BS; $26 \mathrm{~kg} / \mathrm{d})$, all of which were classified as a control group $(n=16)$ because no leaking cows were observed in this herd. Selection of the 2 experimental groups was based upon 1 wk of previous observation at 2 -h intervals within 24 -h periods. The ILA group consisted of cows that presented visible milk leakage from 1 or more teats while recumbent or standing either in the barn or holding pen before milking.

Cows were in their first to fifth lactation and all stages of lactation. Both herds were fed similar diets consisting of corn silage, chopped grass silage, and concentrate. Milking routine was also similar for both herds. Cows in both herds were maintained in loose housing. Milking was performed twice daily at 0445 and $1545 \mathrm{~h}$ in a double- 6 herringbone milking parlor (DeLaval, Harmony cluster, Tumba, Sweden) for cows in herd $\mathrm{A}$ and in a $2 \times 2$ tandem milking parlor (Westfalia Surge GmbH, Biomilker cluster, Oelde, Germany) for cows in herd B. Both the BS and RH control cows were selected to be of similar age, stage of lactation, and milk production as the RH of the ILA group.
At the start of the study period, none of the cows from either herd had clinical symptoms of mastitis or visible traumatic teat injuries.

\section{Experimental Procedures}

Experimental procedures were carried out using only udder quarters with obvious and repeatable signs of milk loss of leakage that was observed during at least 3 consecutive days. Parallel samples were collected from control quarters in different nonleaking cows.

Milk Samples. Samples of cisternal milk, obtained by hand removal (foremilk) before machine milking, and of the main milk fraction including strippings were collected during 4 milking sessions of herd A only. For the cows that freely leaked milk, additional samples were collected at different time intervals from 0 to $5 \mathrm{~h}$ before milking while the cows were either recumbent or standing in the barn. Two procedural treatments were performed on both groups of cows during the 4 milking sessions that occurred in the milking parlor. During 2 of the sessions, cows either did or did not experience prestimulation (udder manipulation) in advance of teat cup attachment. Udder preparation and stimulation consisted of cleaning, forestripping, and drying of teats. Teat cups were attached 1 min after the start of tactile stimulation of the udder.

Samples were analyzed for milk constituents and SCC in the laboratory of the Milchprüfring Bayern e.V. (Wolnzach, Germany). The SCC was analyzed by the fluoro-opto-electronic method (Fossomatic 5000; Foss Electric, Hillerød, Denmark). Aliquots of each sample were frozen at $-20^{\circ} \mathrm{C}$ immediately after sampling for subsequent determination of electrical conductivity (EC) as well as concentrations of $\mathrm{Na}^{+}$and $\mathrm{Cl}^{-}$. The EC was measured at $25^{\circ} \mathrm{C}$ using the LDM electrode from WTW (LDM 130, Wissenschaftlich-Technische-Werkstaetten GmbH, Weilheim, Germany). Sodium and chloride ions dissolved in milk were measured by means of ion-selective electrodes (models 9811 and 9617BN, respectively, Orion Research, Beverly MA).

Milk Flow Measurement. Quarter milk flow was continuously recorded during milking using a mobile recording system (Lactocorder, WMB, Balgach, Switzerland) described previously (Bruckmaier and Blum, 1996). Milk flow traits were evaluated according to Bruckmaier et al. (1995) at a quarter level. Total milk yield $(\mathrm{kg})$, average flow rate $(\mathrm{kg} / \mathrm{min})$, peak flow rate ( $\mathrm{kg} / \mathrm{min})$, main milking time ( $\mathrm{min})$, and time to reach peak flow ( $\mathrm{min}$ ) were analyzed. Milk flow was recorded twice for each cow and stimulation treatment, and visually evaluated for possible failings from, for example, milking claw fall-off during milking. When milk flow 
decreased to $0.2 \mathrm{~kg} / \mathrm{min}$, machine stripping was performed followed by removal of the milking unit.

Milk Fractions and Cisternal Ultrasound. To avoid spontaneous milk ejection during udder manipulation and to accurately determine the amounts of cisternal and alveolar milk fractions separately, cows were moved, shortly before the afternoon milking on 2 consecutive days, to unfamiliar surroundings as indicated by Bruckmaier et al. (1993, 1997). For both groups of cows (ILA and control), the milking claw was attached without any udder preparation. Cisternal milk was removed by machine milking using a single quarter milking claw connected to a Lactocorder. After milk flow stopped, a supraphysiological dose of 10 IU of synthetic oxytocin (OT; Oxytocin-S, Intervet GmbH, Tönisvorst, Germany) was injected into the jugular vein to effect complete removal of the alveolar milk from the quarter. Traits for each milk fraction removed were recorded while the quarter was connected to the mobile recording system (Lactocorder). In the bimodal milk flow curves, occurrence of alveolar milk ejection was detected as the milk flow peak that occurred after removal of cisternal milk (Bruckmaier and Blum, 1996).

Udder quarters were scanned by B-mode ultrasonography with a 3.5-MHz linear array scanner probe (SonoVet 2000, Kretztechnik AG, Zipf, Austria) on the experimental day that followed the recording of the quarter milk fractions. The udder was immersed in a plastic bucket filled with warm water $\left(30\right.$ to $\left.32^{\circ} \mathrm{C}\right)$ to obtain a cross-sectional scan that included gland and teat cisterns. The probe, placed laterally to each quarter, was held in the water without touching the animal (Bruckmaier and Blum, 1992). From the cross-sectional scan, the cisternal area was estimated by measuring the distance between the anterior insertion point of the teat and the posterior skin limit of each quarter using the public domain software (ImageTool, UTHSCSA; version 3.0 for Windows) from the University of Texas Health Sciences Center, San Antonio.

Teat Measurements. Teats were scanned using a 5$\mathrm{MHz}$ linear array scanner probe (B-mode ultrasonography). Teats were dipped in a cup filled with water (30 to $32^{\circ} \mathrm{C}$ ) while the ultrasound probe was attached to the exterior cup wall using an ultrasound contact gel to prevent the presence of air between the probe and cup. The probe was moved until the longitudinal teat cistern was viewed and the teat canal was used as the longitudinal scan axis. Teat scans were performed after 1-min manual teat stimulation in the milking parlor to guarantee a well-filled teat cistern as a result of the initiated milk ejection. Teat wall thickness and teat canal length were measured in duplicate using the computerized image analysis program (ImageTool) by using methods previously described (Neijenhuis et al., 2001;
Weiss et al., 2004). Teat length and width also were determined in duplicate by using a caliper after tactile stimulation of the teat.

IMP. Intramammary pressure was measured in both groups of cows. Measurements in the ILA group occurred just after the cows presented milk leakage while in the barn. For this purpose, cows were under visual observation for several hours before their selection. The IMP was measured before milking in the parlor with a cannula inserted in the teat canal that accommodated a strain gauge system, as previously described (Bruckmaier et al., 1994a). Milk ejection was induced by manual teat stimulation after at least 2 min of recording the baseline pressure $(\mathrm{kPa})$. Manual teat stimulation lasted until IMP increased and a maximum plateau was reached. Variables evaluated were baseline pressure (pressure before start of teat stimulation) and ejection pressure (pressure maximum in response to teat stimulation). Cows were milked immediately after the end of IMP recording.

OT Determination. Blood samples $(10 \mathrm{~mL})$ were obtained from 2 cows in the ILA group after milk leakage was observed. Samples were collected via a catheter inserted in the jugular vein at 2-min intervals starting 60 min before milking (barn and waiting room) until 2 min after the start of milking (milking parlor). Immediately after blood collection, all samples were treated with EDTA to prevent coagulation, cooled on ice, and centrifuged at $1,500 \times g$ for $15 \mathrm{~min}$. Blood plasma was stored at $-20^{\circ} \mathrm{C}$ until OT concentration was determined by RIA (Schams, 1983).

\section{Statistical Analysis}

Degree of udder filling was estimated as a percentage of actual milk yield compared with maximum storage capacity. Maximum storage capacity of the mammary gland was estimated as the greatest milk yield recorded during the current lactation. Udder filling classes were defined according to the degree of udder filling: 40 to $70 \%, 71$ to $80 \%$, and 81 to $100 \%$. During the period studied, none of the cows from either herd had an udder filling $<40 \%$. Effect of parity also was considered and grouped into 3 lactation numbers (1, 2, and 3+). Previous records of clinical mastitis and other udder injuries were included in the initial model to analyze its significance on the occurrence of milk leakage. A small number of cows were selected randomly from both experimental groups (ILA, $\mathrm{n}=9$; control, $\mathrm{RH}=7$ and $\mathrm{BS}=$ 16) to evaluate milk fractions, cisternal ultrasound, and IMP pattern.

Duplicate samples of all variables (except for milk fractions, cistern ultrasound, and OT determination) 
were used and averaged before running the statistical model.

For statistical analysis, a mixed model procedure (PROC MIXED, SAS Institute Inc., Cary, NC) was applied. The model included the fixed effects of herd (A and B), experimental group (ILA and control group) nested within herd, udder filling (40 to $70 \%, 71$ to $80 \%$, and 81 to $100 \%$ ), quarters (rear or front), and number of lactations $(1,2$, or $3+)$, respective interactions, and residual error. Effects of milk samples (milk leakage, cisternal and main milk fraction), stimulation group (with and without prestimulation), and the repeated subject of the animal entered the model to analyze the milk composition in herd A only. When the probability of the interaction term was not significant, it was deleted from the model. Pearson correlation coefficient between cisternal area and cisternal milk was also calculated. Logarithmic transformations $\left(\log _{10}\right)$ of SCC values and arcsine transformation of cisternal milk percentage were made before statistical analysis.

\section{RESULTS}

\section{Milk Samples and Milking Characteristics}

Total milk yields did not differ $(P=0.20)$ between experimental groups $(28,28$, and $27 \mathrm{~kg} / \mathrm{d}$ for the ILA group and control groups from herds $\mathrm{A}$ and $\mathrm{B}$, respectively) at the start of the experiment. Lactation number affected $(P<0.001)$ milk production in which cows in their second or greater lactation produced more milk than cows in their first lactation. Previous clinical mastitis cases were detected in 35 and $6 \%$ of the cows in herds A and B, respectively. Neither herd nor experiment group differed in the number of previous clinical mastitis cases. All studied quarters had reduced SCC levels (Table 1) and remained stable throughout the experiment. Only cows without clinical mastitis symptoms were assigned to experimental groups at the start of the experiment.

Occurrence of leakage in terms of quarter position was 23 vs. 26 observations for front and rear teats, respectively. Proportion of cows leaking in more than 1 teat was $94 \%$ and occurrence of milk leakage was more frequent when cows were lying down.

Milk constituent concentrations differed among the milk leakage, cisternal, and main milk samples (Table 1). Leaking milk samples did not differ from foremilk samples collected without teat stimulation, but differed when compared with foremilk samples collected after udder preparation.

The cows in the ILA group did not present differences in fat content between milk leakage and foremilk before and after teat stimulation. Fat content increased $(P<$ 0.001), however, during main milking in response to milk ejection. Milk electrolytes $\left(\mathrm{Na}^{+}\right.$and $\left.\mathrm{Cl}^{-}\right)$in foremilk were less $(P<0.05)$ in samples collected after udder preparation and remained constant toward the end of milking. Contents of lactose were less $(P<0.05)$ before udder preparation in both groups, but decreased again during milking in the ILA group. Electrical conductivity did not change from the leaking to the foremilk samples without udder preparation for the ILA group. The EC values decreased $(P<0.05)$, however, with successive milk fractions from cisternal without udder preparation to the milking samples for both groups. Milk protein and SCC did not change toward the end of milking.

\section{Milk Flow Profiles}

Representative milk flow patterns for both experimental groups are presented in Figure 1. Evaluations of milk flow in both groups were made on the basis of the curves generated by single quarters. As expected, milking without previous udder preparation caused bimodal milk flow patterns not only in the control, but also in the ILA group. Milking characteristics associated with the quarters are shown in Table 2. The ILA group produced more $(P<0.001)$ quarter milk than the control group from herd A $(+0.65 \mathrm{~kg})$. However, no difference was observed in quarter milk yield between the ILA group and control cows from herd B. Average and peak flow rates were greater $(P<0.05)$ in the ILA group than in controls. Total milking time, duration of plateau and the decrease of milk flow did differ from those in the control.

\section{Milk Fractions and Cisternal Ultrasound}

Cisternal milk yield in the ILA group tended to be greater compared with controls $(P=0.087 ; 0.50 \pm 0.09$ vs. $0.23 \pm 0.11$ and $0.28 \pm 0.06 \mathrm{~kg}$ for ILA and the control group from herd A and B, respectively). Percentage of cisternal milk was numerically greater in ILA than in control cows $(P=0.204 ; 17$ vs. 9 and $9 \%)$ in herds A and B, respectively. Nevertheless, ILA cows did not have more alveolar milk ( $2.44 \pm 0.31$ vs. $2.36 \pm 0.37$ and $2.72 \pm 0.18 \mathrm{~kg}$ ) than controls from herd $\mathrm{A}$ and $\mathrm{B}$, respectively.

Cisternal milk yield was greater $(P<0.05)$ for cows in their second or greater lactation $(0.20$ and $0.45 \mathrm{~kg})$, respectively. Rear quarters had more $(P<0.05)$ alveolar milk than front quarters $(+0.68 \mathrm{~kg})$.

The distance between the anterior insertion point of the teat and the posterior skin limit of each quarter did not differ between groups: 8.04 vs. 8.18 and $8.34 \mathrm{~cm}$ for ILA and control cows in herds A and B, respectively. Cows with 2 or more lactations, however, had deeper $(P<0.01)$ cisterns than first-lactation cows $(9.53$ vs. $6.92 \mathrm{~cm})$. 
ROVAI ET AL.

Table 1. Milk composition during milk removal from mammary quarters of dairy cows ${ }^{1}$

\begin{tabular}{|c|c|c|c|c|}
\hline \multirow[b]{2}{*}{ Milk composition } & \multirow[b]{2}{*}{ Leakage } & \multicolumn{2}{|c|}{ Foremilk $^{2}$} & \multirow[b]{2}{*}{ Milking fraction } \\
\hline & & Without & With & \\
\hline Control & & $(\mathrm{n}=13)$ & $(\mathrm{n}=13)$ & $(\mathrm{n}=26)$ \\
\hline Fat, $\%$ & - & $2.08 \pm 0.23^{\mathrm{a}}$ & $2.06 \pm 0.23^{\mathrm{a}}$ & $4.52 \pm 0.20^{\mathrm{b}}$ \\
\hline Protein, $\%$ & - & $3.91 \pm 0.11$ & $3.82 \pm 0.11$ & $3.77 \pm 0.11$ \\
\hline Lactose, \% & - & $4.43 \pm 0.06^{\mathrm{a}}$ & $4.66 \pm 0.06^{\mathrm{b}}$ & $4.59 \pm 0.06^{\mathrm{b}}$ \\
\hline $\mathrm{Na}^{+}, \mathrm{mmol}$ & - & $22.46 \pm 1.36^{\mathrm{a}}$ & $15.10 \pm 1.32^{\mathrm{b}}$ & $14.51 \pm 1.13^{\mathrm{b}}$ \\
\hline $\mathrm{Cl}, \mathrm{mmol} / \mathrm{L}$ & - & $68.58 \pm 2.69^{a}$ & $56.56 \pm 2.61^{\mathrm{b}}$ & $55.10 \pm 2.25^{\mathrm{b}}$ \\
\hline $\mathrm{EC},{ }^{3} \mathrm{mS} / \mathrm{cm}$ & - & $5.13 \pm 0.10^{\mathrm{a}}$ & $4.80 \pm 0.09^{b}$ & $4.53 \pm 0.09^{c}$ \\
\hline SCC $\left(\log _{10}\right)$ & - & $5.13 \pm 0.18$ & $4.76 \pm 0.18$ & $4.82 \pm 0.15$ \\
\hline Incontinentia lactis & $(\mathrm{n}=59)$ & $(\mathrm{n}=29)$ & $(\mathrm{n}=30)$ & $(\mathrm{n}=59)$ \\
\hline Fat, \% & $1.95 \pm 0.15^{\mathrm{a}}$ & $1.88 \pm 0.18^{\mathrm{a}}$ & $1.95 \pm 0.17^{\mathrm{a}}$ & $4.70 \pm 0.15^{\mathrm{b}}$ \\
\hline Protein, \% & $3.77 \pm 0.09$ & $3.73 \pm 0.10$ & $3.75 \pm 0.10$ & $3.62 \pm 0.10$ \\
\hline Lactose, $\%$ & $4.69 \pm 0.04^{\mathrm{a}}$ & $4.72 \pm 0.05^{\mathrm{a}}$ & $4.83 \pm 0.05^{\mathrm{b}}$ & $4.67 \pm 0.04^{\mathrm{a}}$ \\
\hline $\mathrm{Na}^{+}$, mmol & $17.77 \pm 0.94^{\mathrm{a}}$ & $17.31 \pm 1.01^{\mathrm{a}}$ & $15.11 \pm 1.01^{\mathrm{b}}$ & $13.83 \pm 0.86^{\mathrm{b}}$ \\
\hline $\mathrm{Cl}^{-}, \mathrm{mmol} / \mathrm{L}$ & $61.42 \pm 1.96^{\mathrm{a}}$ & $59.09 \pm 2.07^{\mathrm{a}}$ & $55.09 \pm 2.06^{\mathrm{b}}$ & $52.74 \pm 1.77^{\mathrm{b}}$ \\
\hline $\mathrm{EC}, \mathrm{mS} / \mathrm{cm}$ & $4.85 \pm 0.08^{\mathrm{a}}$ & $4.81 \pm 0.08^{\mathrm{a}}$ & $4.67 \pm 0.08^{\mathrm{b}}$ & $4.39 \pm 0.07^{\mathrm{c}}$ \\
\hline $\operatorname{SCC}\left(\log _{10}\right)$ & $4.94 \pm 0.11$ & $4.90 \pm 0.14$ & $4.75 \pm 0.13$ & $4.84 \pm 0.11$ \\
\hline
\end{tabular}

${ }^{a-c}$ Different letters in the same row indicate significant differences at $P<0.05$.

${ }^{1}$ Values are means \pm SEM. Values taken only from herd A.

${ }^{2}$ Collected on separate days either without or with prestimulation of the udder.

${ }^{3} \mathrm{EC}=$ electrical conductivity.

Correlation between cisternal milk yield and total quarter yield was $\mathrm{r}=0.58(P<0.001)$, and differences were detected between groups (ILA, $\mathrm{r}=0.82$; control, $\mathrm{r}=0.60 ; P<0.01)$. Correlation between cisternal milk and cistern area was $\mathrm{r}=0.47(P<0.01)$.

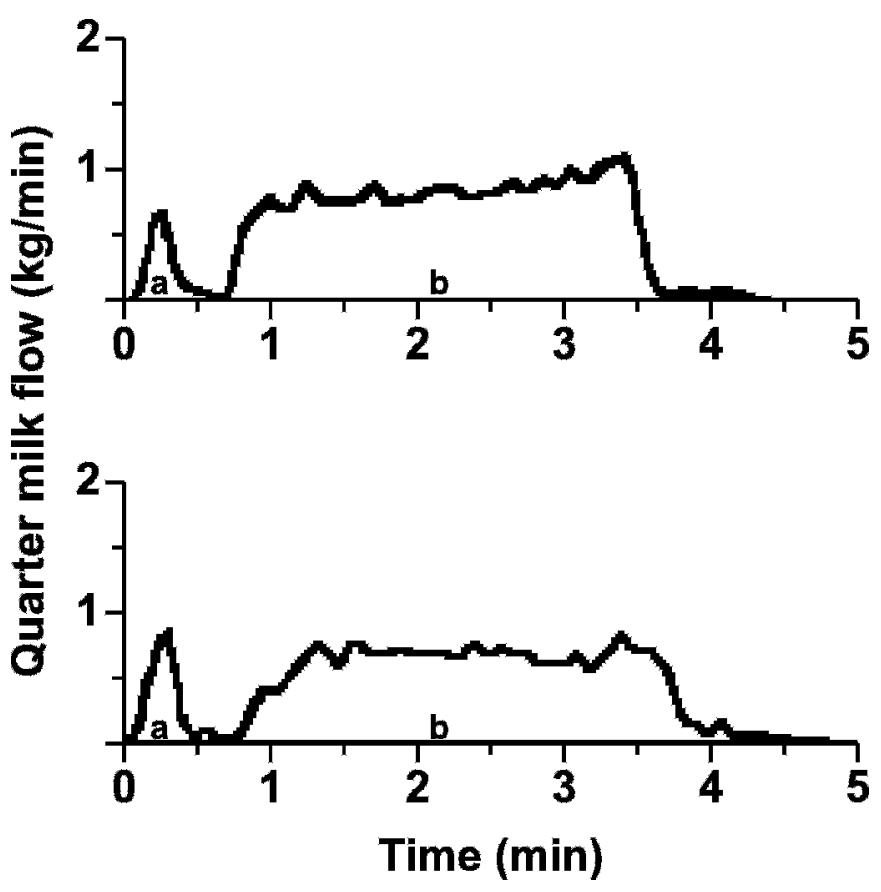

Figure 1. Typical mammary quarter milk flow curves $(\mathrm{a}=$ cisternal milk; $b=$ alveolar milk) for dairy cows in each group: incontinentia lactis cows (top panel) and control cows (bottom panel).

\section{Teat Anatomy}

Brown Swiss (herd B) cows had larger $(P<0.01)$ teats (length and width) than $\mathrm{RH}$ (herd A) cows, as shown in Table 3. Teat wall thickness and teat canal length did not differ between front and rear quarters. Teat canal length was the only anatomical trait that differed between both groups, in which ILA cows had about 9\% shorter $(P<0.05)$ teat canals than the 2 control groups (Table 3).

\section{Milk Ejection and IMP}

The IMP was greater $(P<0.001)$ in the ILA group, both before (baseline) and after manual udder stimulation (ILA: 4.0 and $6.4 \mathrm{kPa}$; control: 2.0 and $5.0 \mathrm{kPa}$; respectively; Figure 2). Induction time from the start of teat stimulation until the start of IMP increase and the ejection time from start of prestimulation until reaching IMP maximum were similar for both groups.

\section{OT Concentrations}

Blood OT patterns of 2 cows from the ILA group before and during milking without teat stimulation are shown in Figure 3. Baseline OT concentrations were low until the start of udder preparation. After teat stimulation and teat cup attachment, concentrations of OT increased in response to the milking stimulus and remained elevated during the course of milking. 
Table 2. Milking characteristics at a quarter level according to group ${ }^{1}$

\begin{tabular}{|c|c|c|c|}
\hline \multirow[b]{2}{*}{ Milk flow trait } & \multicolumn{2}{|c|}{ Control group } & \multirow{2}{*}{$\begin{array}{c}\begin{array}{c}\text { Incontinentia } \\
\text { lactis group }\end{array} \\
\text { Herd A }(\mathrm{n}=36)\end{array}$} \\
\hline & Herd A $(\mathrm{n}=26)$ & Herd B $(\mathrm{n}=32)$ & \\
\hline Total yield, $\mathrm{kg}$ & $2.51 \pm 0.20^{\mathrm{a}}$ & $2.98 \pm 0.18^{\mathrm{ab}}$ & $3.16 \pm 0.19^{b}$ \\
\hline Peak flow rate, $\mathrm{kg} / \mathrm{min}$ & $0.79 \pm 0.05^{\mathrm{a}}$ & $0.64 \pm 0.05^{\mathrm{b}}$ & $1.13 \pm 0.05^{\mathrm{c}}$ \\
\hline Duration of plateau, min & $2.48 \pm 0.37$ & $3.10 \pm 0.35$ & $2.30 \pm 0.33$ \\
\hline Duration of decline, min & $1.29 \pm 0.31$ & $0.92 \pm 0.29$ & $1.00 \pm 0.28$ \\
\hline Main milking time, min & $3.96 \pm 0.37$ & $4.13 \pm 0.35$ & $3.48 \pm 0.33$ \\
\hline Average flow rate, $\mathrm{kg} / \mathrm{min}$ & $0.54 \pm 0.05^{\mathrm{a}}$ & $0.49 \pm 0.05^{\mathrm{a}}$ & $0.84 \pm 0.04^{b}$ \\
\hline Time to reach peak flow, min & $1.11 \pm 0.07$ & $0.95 \pm 0.07$ & $0.96 \pm 0.06$ \\
\hline
\end{tabular}

${ }^{\mathrm{a}-\mathrm{c}}$ Different letters within a row indicate significant differences at $P<0.05$.

${ }^{1}$ Values are means \pm SEM.

\section{DISCUSSION}

The novel observation from this experiment was that the condition of milk leakage is independent of the milk ejection reflex. Overall, causes of milk leakage were not related to milk production, age, or stage of lactation. Milk losses via leakage were associated with large amounts of cisternal milk yield that created pressure, and thus, by increasing IMP, eventually caused the leakage of milk from the shorter teat canals.

In this study, no clear evidence was found that incontinentia lactis increased the risk of mammary infection. Because this research, however, was conducted during autumn and winter, the probability of increased mastitis susceptibility cannot be excluded. Previous reports focused on the importance of milk leakage onto bedding and increasing environmental exposure to pathogens and consequently an increased rate of clinical mastitis (Elbers et al., 1998; Waage et al., 1998; Peeler et al., 2000). Milk leakage in our study was more likely to occur from an individual quarter than from all 4 quarters of the udder. Of cows showing milk leakage, only 3 were observed to leak milk from all quarters in contrast to another report (Klaas et al., 2005). Dripping of milk was observed when cows were both lying and standing in the dairy barn. Proportion of leaking was more often when cows were recumbent, in agreement with Persson Waller et al. (2003). The same authors reported, in contrast to our results, that milk leakage occurred more often in rear than in front quarters. Differences in incidence of milk leakage among other studies could have occurred because of different observation schedules, milking systems, and breeds of cows.

\section{Milk Samples and Milking Characteristics}

Values for milk constituents were in the range reported by others (Hamann and Gyodi, 1994; Wellnitz et al., 1999; Persson Waller et al., 2003).

The fat content of leaking milk samples did not differ from that of foremilk samples collected before teat stimulation. The values, however, were lower when compared with foremilk samples collected after udder preparation. Once milk let-down is triggered, a continuous increase in fat content is observed from cisternal to alveolar fractions during milking (Ontsouka et al., 2003; Bruckmaier et al., 2004a; Sarikaya et al., 2005). The present findings indicated that milk leakage cannot be explained by the release of OT and induction of the milk ejection reflex (Figure 3).

The EC and milk electrolytes $\left(\mathrm{Na}^{+}\right.$and $\left.\mathrm{Cl}^{-}\right)$did not change between leaking and foremilk samples without prestimulation (Table 1). These milk characteristics, however, decreased during milking in accordance with previous results (Ontsouka et al., 2003; Bruckmaier et al., 2004a,b). Such changes in EC can be partially

Table 3. Teat anatomy according to group ${ }^{1}$

\begin{tabular}{llll}
\hline & \multicolumn{2}{c}{ Control group } & Incontinentia \\
\cline { 2 - 3 } Teat trait & Herd A & Herd B & Herd A \\
\hline Length, cm & $4.97 \pm 0.17^{\mathrm{a}}$ & $5.56 \pm 1.01^{\mathrm{b}}$ & $5.05 \pm 0.13^{\mathrm{a}}$ \\
Width, cm & $2.39 \pm 0.05^{\mathrm{a}}$ & $2.61 \pm 0.04^{\mathrm{b}}$ & $2.42 \pm 0.04^{\mathrm{a}}$ \\
Wall, cm & $0.71 \pm 0.03$ & $0.71 \pm 0.02$ & $0.71 \pm 0.02$ \\
Canal length, cm & $1.26 \pm 0.03^{\mathrm{a}}$ & $1.29 \pm 0.02^{\mathrm{a}}$ & $1.17 \pm 0.02^{\mathrm{b}}$ \\
\hline
\end{tabular}

${ }^{\mathrm{a}, \mathrm{b}}$ Different letters within a row indicate significant differences at $P<0.05$.

${ }^{1}$ Values are means \pm SEM. 


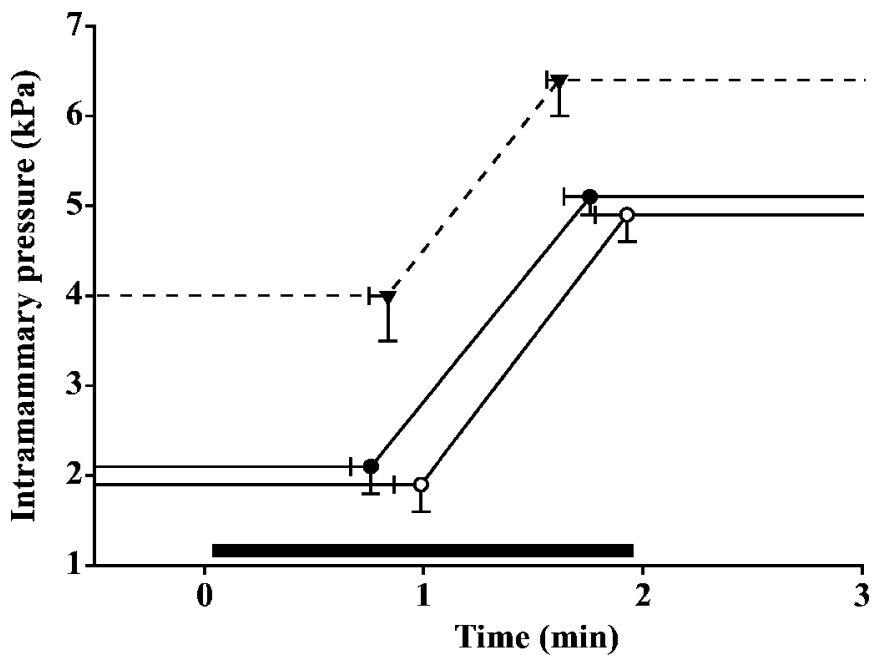

Figure 2. Intramammary pressure in the incontinentia lactis group after leakage had begun $(\boldsymbol{\nabla}$, dashed line; $\mathrm{n}=9)$, and in control cows from herd $\mathrm{A}(\mathrm{O}$, solid line; $\mathrm{n}=7)$ and herd $\mathrm{B}(-$, solid line; $\mathrm{n}=$ 16). Values are means \pm SEM. Period of manual teat stimulation is shown by the thick black bar.

explained by the simultaneous increase in milk fat content, which has been identified as a factor that decreases EC (Fernando et al., 1981; Hamann et al., 1995; Woolford et al., 1998).

Consistent with previous observations (Bruckmaier et al., 1995; Bruckmaier and Blum, 1996; Bruckmaier and Hilger, 2001), control and ILA cows had a transient reduction in milk flow after removal of cisternal milk and before alveolar milk ejection at milking without prestimulation resulting in a bimodal curve (Figure 1). This observation indicated that in ILA cows, milk ejection had not occurred before tactile udder stimulation. Thus, leakage was not a consequence of milk ejection.

Results for milking characteristics (Table 2) are in accordance with Wellnitz et al. (1999) and Weiss et al. (2004) for both herds and for ILA and control groups. Although production levels were similar for cows in herds A and B, milk leakage did not occur in herd B. The greater average and peak flow rates for the ILA group are in agreement with another report (Persson Waller et al., 2003) for cows that leaked milk, in systems in which cows were milked with automatic milking systems. These results indicate that the cause of milk leakage and of greater milk flow rates is not solely a characteristic of high-producing cows. Klaas et al. (2005), in a study conducted on 15 commercial dairy farms ( 49 cows) of different breeds, reported that even lower yielding primiparous cows with greater peak milk flow rates were at risk for leakage.

\section{Milk Fractions and Cisternal Ultrasound}

Distribution of milk within the udder was similar to that reported elsewhere (Wellnitz et al., 1999; Ayadi et al., 2003). Cows in the ILA group tended to have more cisternal milk than control cows, but similar cisternal volume. Differences between groups can be explained by the greater milk synthesis and secretion of ILA cows as evidenced by quarter milk yield values (Table 2). The greater correlation between cisternal milk and total quarter yield for the ILA group is probably related to differences observed in the cisternal storage capacities of the experimental groups.

\section{Teat Anatomy}

Means for teat size (Table 3) were within the ranges reported previously for each breed (Rogers and Spencer, 1991; Neijenhuis et al., 2001; Weiss et al., 2004). Front teats were longer than rear teats $(+0.9 \mathrm{~cm})$, similar to other reports (Rogers and Spencer, 1991; Neijenhuis et al., 2001; Weiss et al., 2004). Teat diameter did not differ between front and rear teats. Teat shape in general did not increase the risk of milk leakage in either experimental group, in agreement with Klaas et al. (2005). These authors, however, determined that teat canal protrusions and inverted teat end shapes were greater risk factors for leakage. It has to be considered that no teat traumas were observed during the study.

The slightly shorter teat canals found in cows in the ILA group could be partially responsible for occurrence of milk leakage. The main problem related to the teat canal length is its influence on the passage of pathogens through the canal, and thus susceptibility to IMI (LacyHulbert and Hillerton, 1995).

\section{Milk Ejection and IMP}

The elevated IMP of the ILA group mostly before milking and immediately after the onset of milk leakage could be an important cause for milk leakage and is likely caused by more ejected milk. Entry of alveolar milk into the mammary ducts and gland cavities before milk removal causes an increase of IMP within the cistern (Bruckmaier et al., 1991; Mayer et al., 1991; Bruckmaier and Blum, 1996). Nevertheless, increased IMP in response to udder preparation affirms the occurrence of milk ejection in response to the tactile teat stimulation and is not related to the onset of leaking.

The larger cisternal size (cisternal milk) and greater IMP in ILA cows are directly related to a large capacity of milk ejection in high-performance cows, and consequently, the greater milk flow rates of this group. These results are in agreement with Wellnitz et al. (1999), who showed that the greater IMP after milk ejection 

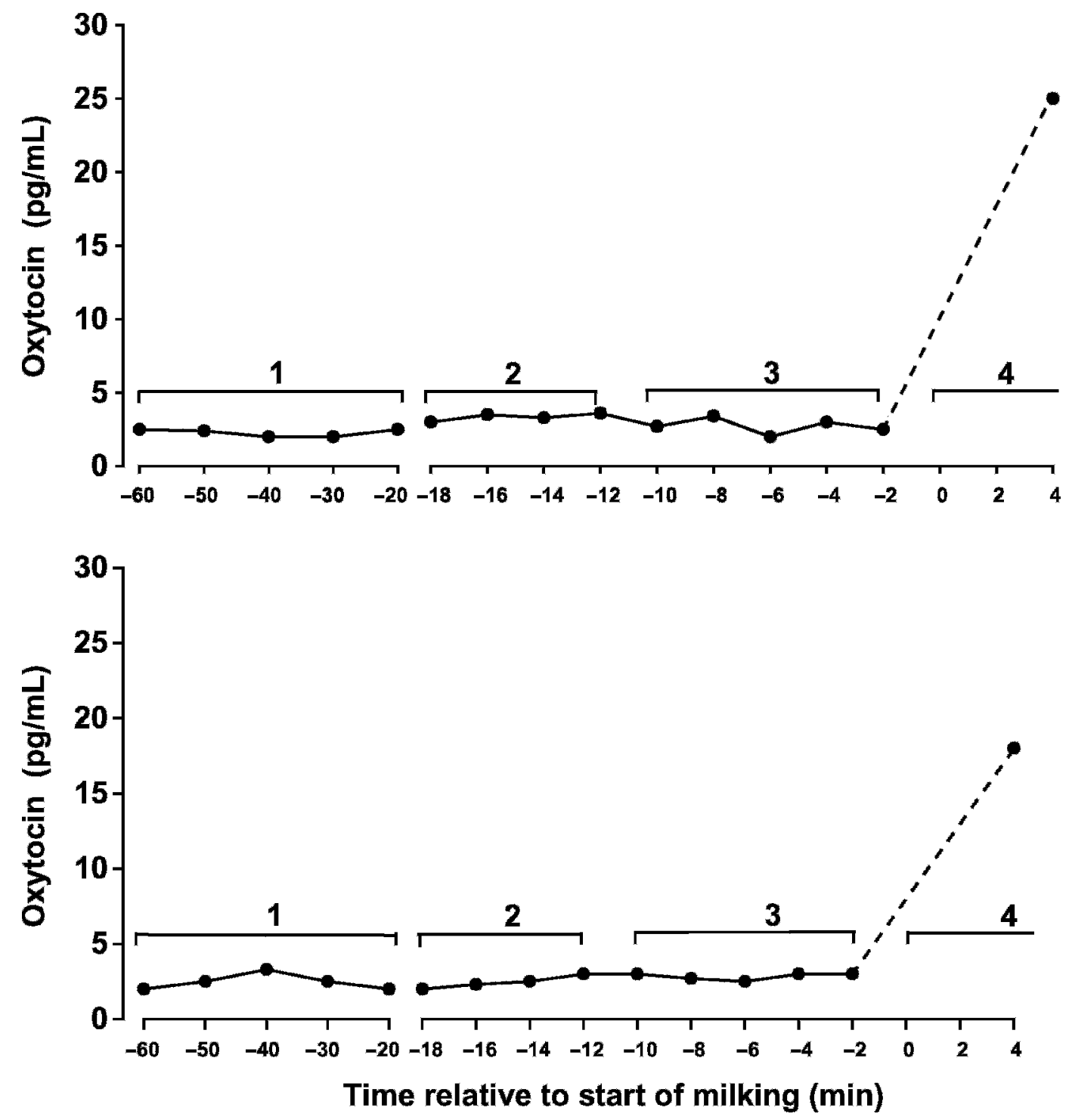

Figure 3. Blood oxytocin concentrations of 2 cows in the incontinentia lactis group in the barn (1), during walking (2) to the waiting room (3), and at the milking parlor (4). Start of milking without previous prestimulation was at 0 min.

in high-yielding cows compared with lower yielding cows was caused by more ejected milk in the former. Duration of time from the start of teat stimulation until the start of IMP increase (induction time) and until IMP maximum (ejection time) were similar for both experimental groups (Figure 2). These results indicate that the time course of milk ejection is not different between production levels as previously reported by Wellnitz et al. (1999).

\section{Blood OT Pattern}

Blood concentrations of OT in ILA cows did not increase until after teat stimulation and teat cup attach- ment, reaffirming the hypothesis that onset of leakage occurs in the absence of milk ejection (Figure 3). A similar blood pattern of OT was described in previous studies (Bruckmaier et al., 1994b; Bruckmaier and Blum, 1998; Macuhova et al., 2004). Premilking udder preparation and the milking session are important management factors that evoke the milk ejection response and consequently optimize milk removal.

Further research is needed on the effect of milk leakage and the potential risk factors (animal management, environmental conditions, and various hygiene issues) that predispose development of mastitis in herds with leaking cows.

In conclusion, because milk leakage is exclusively from the cisterns, milk ejection is not responsible for 
this loss of milk. A more plausible cause of incontinentia lactis is the elevated IMP caused by a large amount of cisternal milk in the ILA cows. Milk leakage was not detected as a cause for increased mastitis susceptibility in our study. The possibility of increased environmental exposure to pathogens during milk leakage in dairy cows cannot be excluded.

\section{REFERENCES}

Ayadi, M., G. Caja, X. Such, and C. H. Knight. 2003. Use of ultrasonography to estimate cistern size and milk storage at different milking intervals in the udder of dairy cows. J. Dairy Res. 70:1-7.

Barkema, H. W., Y. H. Schukken, T. J. G. M. Lam, M. L. Beiboer, G. Benedictus, and A. Brand. 1999. Management practices associated with the incidence rate of clinical mastitis. J. Dairy Sci. 82:1643-1654.

Baxter, E. S., P. M. Clarke, F. H. Dodo, and A. S. Foot. 1950. Factors affecting the rate of machine milking. J. Dairy Res. 17:117-127.

Bruckmaier, R. M., and J. W. Blum. 1992. B-mode ultrasonography of mammary glands of cows, goats and sheep during $\alpha$ - and $\beta$ adrenergic agonist and oxytocin administration. J. Dairy Res. 59:151-159.

Bruckmaier, R. M., and J. M. Blum. 1996. Simultaneous recording of oxytocin release, milk ejection and milk flow during milking of dairy cows with and without prestimulation. J. Dairy Res. 63:201-208.

Bruckmaier, R. M., and J. W. Blum. 1998. Oxytocin release and milk removal in ruminants. J. Dairy Sci. 81:939-949.

Bruckmaier, R. M., and M. Hilger. 2001. Milk ejection in dairy cows at different degrees of udder filling. J. Dairy Res. 68:369-376.

Bruckmaier, R. M., H. Mayer, and D. Schams. 1991. Effects of alphaand beta-adrenergic agonists on intramammary pressure and milk flow in dairy cows. J. Dairy Res. 58:411-419.

Bruckmaier, R. M., C. E. Ontsouka, and J. W. Blum. 2004a. Fractionized milk composition in dairy cows with subclinical mastitis. Vet. Med. Czech 49:283-290.

Bruckmaier, R. M., E. Rothenanger, and J. W. Blum. 1994a. Measurement of mammary gland cistern size and determination of the cisternal milk fraction in dairy cows. Milchwissenchaft 49:543546.

Bruckmaier, R. M., E. Rothenanger, and J. W. Blum. 1995. Milking characteristics in dairy cows of different breeds from different farms and during the course of lactation. J. Anim. Breed. Genet. 112:293-302.

Bruckmaier, R. M., D. Schams, and J. W. Blum. 1993. Milk removal in familiar and unfamiliar surroundings: Concentration of oxytocin, prolactin, cortisol and $\beta$-endorphine. J. Dairy Res. 60:449-456.

Bruckmaier, R. M., D. Schams, and J. W. Blum. 1994b. Continuously elevated concentrations of oxytocin during milking are necessary for complete milk removal in dairy cows. J. Dairy Res. 61:323-334.

Bruckmaier, R. M., D. Weiss, M. Wiedemann, S. Schmitz, and G. Wendl. 2004b. Changes of physicochemical indicators during mastitis and the effects of milk ejection on their sensitivity. J. Dairy Res. 71:316-321.

Bruckmaier, R. M., O. Wellnitz, and J. M. Blum. 1997. Inhibition of milk ejection in cows by oxytocin receptor blockade, $\alpha$-adrenergic receptor stimulation and in unfamiliar surroundings. J. Dairy Res. 60:449-456.

Elbers, A. R. W., J. D. Miltenburg, D. de Lange, A. P. P. Crauwels, H. W. Barkema, and Y. H. Schukken. 1998. Risk factors for clinical mastitis in a random sample of dairy herds from the southern part of the Netherlands. J. Dairy Sci. 81:420-426.
Fernando, R. S., R. B. Rindsig, and S. L. Spahr. 1981. Effect of length of milking interval and fat content on milk conductivity and its use for detecting mastitis. J. Dairy Sci. 64:668-682.

Grindal, R. J., and J. E. Hillerton. 1991. Influence of milk flow rate on new intramammary infection in dairy cows. J. Dairy Res. $58: 263-268$.

Hamann, J., and P. Gyodi. 1994. Effects on milk yield, somatic cell count and milk conductivity of short-term non-milking of lactating quarters of cows. J. Dairy Res. 61:317-322.

Hamann, J., B. Nipp, and P. Gyodi. 1995. Comparison of hand-held instruments for measuring the electrical conductivity of milk. Milchwissenschaft 50:543-546.

Klaas, C., C. Enevoldsen, A. K. Ersboll, and U. Tölle. 2005. Cowrelated risk factors for milk leakage. J. Dairy Sci. 88:128-136.

Lacy-Hulbert, S. J., and J. E. Hillerton. 1995. Physical characteristics of the bovine teat canal and their influence on susceptibility to streptococcal infection. J. Dairy Res. 62:395-404.

Macuhova, J., V. Tancin, and R. M. Bruckmaier. 2004. Effects of oxytocin administration on oxytocin release and milk ejection. J. Dairy Sci. 87:1236-1244.

Mayer, H., R. M. Bruckmaier, and D. Schams. 1991. Lactational changes in oxytocin release, intramammary pressure and milking characteristics in dairy cows. J. Dairy Res. 58:159-169.

Neijenhuis, F., G. H. Klungel, and H. Hogeveen. 2001. Recovery of cow teats after milking as determined by ultrasonographic scanning. J. Dairy Sci. 84:2599-2606.

Ontsouka, C. E., R. M. Bruckmaier, and J. W. Blum. 2003. Fractionized milk composition during removal of colostrum and mature milk. J. Dairy Sci. 86:2005-2011.

Peeler, E. J., M. J. Green, J. L. Fitzpatrick, K. L. Morgan, and L. E. Green. 2000. Risk factors associated with clinical mastitis in low somatic cell count British dairy herds. J. Dairy Sci. 83:2464-2472.

Persson Waller, K., T. Westermark, T. Ekman, and K. SvennerstenSjaunja. 2003. Milk leakage-An increased risk in automatic milking systems. J. Dairy Sci. 86:3488-3497.

Rogers, G. W., and S. B. Spencer. 1991. Relationship among udder and teat morphology and milking characteristics. J. Dairy Sci. 74:4189-4194.

Sarikaya, H., C. Werner-Misof, M. Atzkern, and R. M. Bruckmaier. 2005. Distribution of leucocyte populations, and milk composition, in milk fractions of healthy quarters in dairy cows. J. Dairy Res. 72:486-492.

Schams, D. 1983. Oxytocin determination by radioimmunoassay. III. Improvement to subpicogram sensitivity and application to blood levels in cyclic cattle. Acta Endocrinol. (Copenh.) 103:180-183.

Schukken, Y. H., F. J. Grommers, D. Van de Geer, H. N. Erb, and A. Brand. 1990. Risk factors for clinical mastitis in herds with a low bulk milk somatic cell count. 1. Data and risk factors for all cases. J. Dairy Sci. 73:3463-3471.

Schukken, Y. H., F. J. Grommers, D. Van de Geer, H. N. Erb, and A. Brand. 1991. Risk factors for clinical mastitis in herds with a low bulk milk somatic cell count. 2. Risk factors for Escherichia coli and Staphylococcus aureus. J. Dairy Sci. 74:826-832.

Schukken, Y. H., J. Vanvliet, D. Van de Geer, and F. J. Grommers. 1993. A randomized blind trial on dry cow antibiotic infusion in a low somatic cell count herd. J. Dairy Sci. 76:2925-2930.

Waage, S., S. Sviland, and S. A. Odegaard. 1998. Identification of risk factors for clinical mastitis in dairy heifers. J. Dairy Sci. 8:1275-1284.

Weiss, D., M. Weinfurtner, and R. M. Bruckmaier. 2004. Teat anatomy and its relationship with quarter and udder milk flow characteristics in dairy cows. J. Dairy Sci. 87:3280-3289.

Wellnitz, O., R. M. Bruckmaier, and J. W. Blum. 1999. Milk ejection and milk removal of single quarters in high yielding dairy cows. Milchwissenschaft 54:303-306.

Woolford, M. W., J. H. Williamson, and H. V. Henderson. 1998. Changes in electrical conductivity and somatic cell count between milk fractions from quarters subclinically infected with particular mastitis pathogens. J. Dairy Res. 65:187-198. 